\title{
KEANEKARAGAMAN SERANGGA AIR DAN BIOMONITORING BERBASIS INDEKS FAMILI BIOTIK
}

\section{(Diversity of Aquatic Insects and Biomonitoring Based on Family Biotic Index)}

\author{
Sitti Nuraeni*, Asma'ul Khusna HM, dan/and Andi Sadapotto
}

Program Studi Kehutanan, Fakultas Kehutanan Universitas Hasanuddin Kampus Unhas Tamalanrea Jl. P. Kemerdekaan Km. 10 Makassar 90245, Sulawesi Selatan, Indonesia

\begin{tabular}{|c|c|}
\hline Info artikel: & ABSTRACT \\
\hline $\begin{array}{l}\text { Keywords: } \\
\text { waters quality, } \\
\text { bioindicator insect, } \\
\text { family biotic index }\end{array}$ & $\begin{array}{l}\text { The Salima River, located in the Educational Forest of Hasanuddin University, is always } \\
\text { open for educational, research and technological purposes and is also open to the } \\
\text { surrounding community. Various community activities around the education forest may } \\
\text { change the quality of river ecosystems or can be an anthropogenic disturbance. This study } \\
\text { aims to determine the diversity of aquatic insects and assess water quality based on family } \\
\text { as an indicator in biomonitoring. Research and sampling were carried out in the upstream, } \\
\text { middle and downstream parts of the Salima River. Collected aquatic insect samples then } \\
\text { were identified and analyzed. Observations of diversity, water wealth and water quality } \\
\text { were carried out using the Shannon-Wiener index (H') and the Hilsenhoff Family Biotic } \\
\text { Index (HFBI) index method. The Salima River aquatic insect diversity index from upstream } \\
\text { to downstream ranges from } 2.04-1.11 \text { (medium category). The wealth index in the upstream } \\
\text { part of } 1.05 \text { (medium) and in the middle to the downstream were } 0.61 \text { and } 0.40 \text { respectively } \\
\text { (low). Salima river water quality on the upstream side was considered as very good (HFBI } \\
\text { value 3) while the middle and downstream parts were considered as good category (HFBI } \\
\text { value 4). The results of this study will be preliminary data for the assessment of } \\
\text { environmental changes over time in the same location and can be used to assess the } \\
\text { implications of excessive access by the public on using the education forest. }\end{array}$ \\
\hline
\end{tabular}

\section{Kata kunci:}

kualitas perairan, serangga

bioindikator, indeks famili biotik

\begin{abstract}
ABSTRAK
Sungai Salima terletak di Hutan Pendidikan Universitas Hasanuddin selalu terbuka untuk tujuan pendidikan, riset dan teknologi dan juga terbuka bagi masyarakat di sekitarnya. Berbagai aktivitas masyarakat di sekitar hutan pendidikan tersebut dikhawatirkan dapat mengubah kualitas ekosistem sungai atau dapat menjadi gangguan yang bersifat antropogenik. Penelitian ini bertujuan untuk mengetahui keanekaragaman serangga akuatik dan menilai kualitas perairan berdasarkan famili sebagai indikator dalam biomonitoring. Penelitian dan pengambilan sampel dilakukan pada bagian hulu, tengah dan hilir Sungai Salima. Sampel serangga akuatik yang dikumpulkan diidentifikasi dan dianalisis. Pengamatan keanekaragaman, kekayaan dan kualitas air dilakukan dengan menggunakan metode indeks Shannon-Wiener (H') dan Hilsenhoff Family Biotic Index (HFBI). Indeks keanekaragaman serangga aquatik Sungai Salima dari hulu sampai hilir berkisar 2,04 - 1,11 (kategori sedang). Indeks kekayaan pada bagian hulu 1,05 tergolong kategori sedang dan pada bagian tengah sampai hilir masing-masing 0,61 dan 0,40 tergolong kategori rendah. Kualitas perairan Sungai Salima pada bagian hulu masih sangat baik (Nilai HFBI 3), sedangkan bagian tengah dan hilir termasuk kategori baik (nilai HFBI 4). Hasil penelitian ini akan menjadi data awal untuk penilaian perubahan lingkungan dari waktu ke waktu pada lokasi yang sama dan dapat digunakan untuk menilai implikasi atas akses yang berlebihan oleh masyarakat pada pemanfaatan hutan pendidikan.
\end{abstract}




\section{PENDAHULUAN}

Serangga berhasil menempati semua bentuk habitat di daratan, perairan air tawar dan bahkan sekitar batas pasang surut air laut (Gullan \& Cranston, 2014; Schowalter, 2016). Serangga merupakan salah satu kelompok hewan yang mempunyai tingkat keanekaragaman yang tinggi mencakup 70\% dari keseluruhan spesies yang ada di muka bumi (Samways, 2018). Sekelompok serangga yang sebagian dari siklus hidupnya atau menghabiskan seluruh fase hidupnya di dalam air lebih dikenal sebagai serangga akuatik (Prommi \& Payakka, 2015). Serangga akuatik memiliki peranan penting dalam ekosistem perairan. Menurut Nair et al. (2015), salah satu arti penting serangga akuatik dalam ekosistem air adalah dapat digunakan sebagai biomonitoring kesehatan lingkungan perairan. Keberadaan serangga akuatik perlu menjadi perhatian bagi banyak pihak sebagai bagian kekayaan dan keanekaragaman hayati.

Salah satu indeks penilaian kualitas perairan adalah menggunakan analisis tingkat toleransi kehadiran beberapa famili dari ordo-ordo serangga tertentu atau disebut juga serangga sebagai biomonitoring (Chouldhary \& Ahi, 2015). Salah satu metode yang dapat digunakan untuk mengukur kualitas perairan adalah metode Hilsenhoff Family Biotic Index (HFBI) yang dikembangkan oleh Hilsenhoff (1988). Metode ini menggunakan kehadiran beberapa familia serangga dengan nilai toleransi tertentu pada suatu habitat perairan. Penggunaan HFBI bermanfaat untuk mengevaluasi status umum pencemaran organik sungai untuk tujuan-tujuan lebih lanjut, yang dapat dimanfaatkan sebagai prosedur penilaian kualitas secara cepat. HFBI lebih fokus mengkaji toleransi famili serangga dibandingkan dengan menggunakan Biotic Index (BI) hasilnya kurang akurat dan lebih sering mengarah pada kesimpulan yang salah tentang kualitas air (Hilsenhoff, 1988).

Hutan Pendidikan Universitas
Hasanuddin (Unhas) yang berada di Kecamatan Cenrana, Kabupaten Maros ditetapkan untuk pengembangan ilmu pengetahuan, penelitian dan teknologi yang menjadi sumber kekayaan alam, baik dari hasil hutan kayu, non kayu dan kekayaan alam hayati maupun non hayati lainnya. Selain untuk pengembangan dunia pendidikan, penelitian dan teknologi. Hutan Pendidikan Unhas juga sangat terbuka untuk diakses oleh masyarakat umum disekitarnya.

Akses yang terbuka bagi masyarakat di sekitar Hutan Pendidikan menjadi sangat rawan terjadinya masalah. Masalah yang mungkin terjadi akibat pemanfaatan lahan dari pembukaan berbagai aktivitas pertanian adalah dampak negatif bagi lingkungan. Salah satu contoh pemanfaatan lahan adalah pembukaan persawahan dan pemanfaatan sumber air dari beberapa sungai yang ada di dalam Hutan Pendidikan termasuk Sungai Salima. Sungai ini juga merupakan suatu habitat tersendiri untuk berbagai biota perairan sungai. Berbagai aktivitas masyarakat tersebut dapat merubah kualitas ekosistem sungai atau dapat menjadi gangguan bersifat antropogenik terutama jika ada penggunaan insektisida. Oleh karena itu, penelitian ini bertujuan untuk mengetahui keanekaragaman serangga akuatik dan menjadikan beberapa familia dari ordo tertentu sebagai biomonitoring berbasis HFBI untuk penilaian kualitas perairan Sungai Salima di Hutan Pendidikan Unhas.

\section{BAHAN DAN METODE}

\section{A. Waktu dan Lokasi Penelitian}

Penelitian ini dilaksanakan pada Bulan Maret sampai April 2018, lokasi penelitian dilakukan di aliran Sungai Salima yang berada pada wilayah Hutan Pendidikan Unhas Kabupaten Maros, Sulawesi Selatan (Gambar 1). Penentuan titik pengambilan sampel dilakukan pada 3 (tiga) area yakni bagian hulu, tengah dan hilir sungai. Bagian hulu Sungai Salima 
terletak pada posisi antara $119^{\circ} 45^{\prime} 40^{\prime \prime}$ $119^{\circ} 45^{\prime} 44^{\prime \prime}$ BT dan 4 $58^{\prime} 34^{\prime \prime}$ - 4 $4^{\circ} 58^{\prime} 35^{\prime \prime}$ LS ditandai dengan adanya air terjun pada bagian ini. Bagian tengah terletak pada posisi antara $119^{\circ} 46^{\prime} 99^{\prime \prime}-119^{\circ} 46^{\prime} 11^{\prime \prime}$ BT dan $4^{\circ} 59^{\prime} 2^{\prime \prime}$ - $4^{\circ} 59^{\prime} 4$ " LS ditandai dengan adanya air yang cukup deras dan tergenang di beberapa tempat. Bagian hilir pada posisi antara $119^{\circ} 46^{\prime} 3$ " - $119^{\circ} 47^{\prime} 4^{\prime \prime}$ BT dan 4 $59^{\prime} 3$ " $-4^{\circ} 60^{\prime} 4$ " LS ditandai dengan adanya air yang cukup deras dan tergenang di beberapa tempat, serta adanya bebatuan besar.

\section{B. Bahan dan Alat Penelitian}

Bahan yang digunakan yakni serangga-serangga akuatik fase dewasa atau pradewasa yang ditemukan pada tiga area pengamatan (hulu, tengah dan hilir) Sungai Salima, alkohol 70\%, data sheet, dan kertas label. Alat yang digunakan dalam penelitian ini adalah $G P S$, jaring perangkap serangga (kick net dan pond net), pinset, talang penampungan spesimen sementara, botol spesimen, kamera, alat tulis menulis dan mikroskop stereo.

\section{Pelaksanaan Penelitian}

Titik lokasi pengambilan sampel dilakukan pada tiga titik arah berlawanan sisi tepi kiri kanan sungai pada masing- masing bagian hulu, tengah dan hilir sungai. Bagian hilir menjadi awal pengambilan sampel kemudian disusul bagian tengah dan terakhir pada bagian hulu. Jarak hilir ke tengah 800 m (karena kendala bebatuan) dan tengah ke hulu $1.400 \mathrm{~m}$. Pengambilan sampel dilakukan dengan teknik jabbing dan kicking pada arus yang tidak terlalu deras dan dangkal dengan cara meletakkan jaring menghadap ke arah hulu atau mengarah ke datangnya aliran air. Teknik jabbing dilakukan di tepi sampai ke tengah lebar badan sungai dan mengarahkan ayunan jaring berlawanan aliran air sepanjang $5 \mathrm{~m}$. Jumlah ayunan jabbing dan pemasangan kicking sebanyak masing-masing tiga kali ayunan sehingga ada 18 kali pengambilan sampel per bagian sungai. Teknik kicking dilakukan dengan mengaduk aduk substrak lumpur, pasir dan batuan kecil di depan jaring selama satu menit sepanjang $5 \mathrm{~m}$. Semua sampel yang terperangkap pada jaring segera dipindahkan pada talang sampel sementara. Sampel dipisahkan dari substrak dan segera dimasukkan ke dalam botol-botol sampel untuk proses identifikasi lanjut. Identifikasi sampel dilakukan di laboratorium dengan mengacu pada Morse (2009) dan Easton, Huselid, \& Abreu (2012).

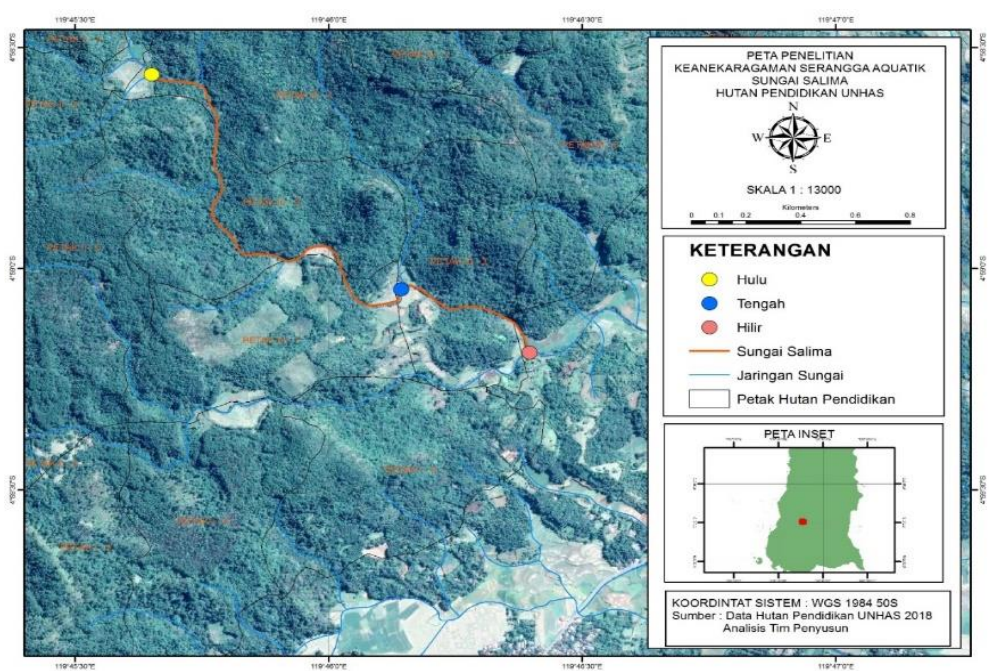

Gambar (Figure) 1. Peta Lokasi Penelitian: hulu, tengah dan hilir Sungai Salima (Research Location Map: upstream, middle and downstream parts of the Salima River). 


\section{Analisis Data}

Data serangga aquatik dianalisis untuk mendapatkan nilai indeks keanekaragaman dan kekayaan jenis sesuai metode analisis data Indeks ShannonWiener (Magurran, 2004; Schowalter, 2016). Untuk menentukan famili serangga akuatik yang dapat dijadikan biomonitoring kualitas perairan dengan menggunakan Hilsenhoff family biotic index (HFBI) (Hilsenhoff, 1988).

Nilai indeks keanekaragaman jenis digunakan pula untuk menentukan kategori keanekaragaman jenis. Tingkat toleransi masing-masing famili dari berbagai ordo serangga berbeda-beda (Tabel 1) dan kualitas air dinyatakan dalam beberapa level berdasarkan nilai HFBI (Tabel 2).

\section{HASIL DAN PEMBAHASAN}

\section{A. Kondisi umum lokasi penelitian}

Sungai Salima termasuk salah satu sungai yang ada dalam area Hutan Pendidikan Unhas yang membentang dari arah barat laut sampai ke tenggara sepanjang lebih dari $2 \mathrm{~km}$. Bagian hulu Sungai Salima berada pada ketinggian \pm $442 \mathrm{~m}$ di atas permukaan laut. Bagian hulu ini ditandai dengan adanya air terjun dan pada bagian ini kondisi air relatif jernih (Gambar 2A). Benda-benda di bagian dasar sungai dapat terlihat jelas seperti pasir, kerikil maupun bebatuan, sehingga keberadaan serangga dapat terlihat pula dengan jelas. Vegetasi pada bahu sungai didominasi oleh Aleuritas moluccana,
Pinus mercusii, Callophylum sp., dan vegetasi tumbuhan bawah berupa tanaman paku-pakuan. Pada bagian hulu Sungai Salima dimanfaatkan sebagai sumber air bersih yang dialirkan menggunakan pipa untuk kebutuhan air bersih masyarakat.

Bagian tengah Sungai Salima memiliki badan air yang sebagian mengalir dan sebagian tergenang di beberapa tempat (Gambar 2B). Kondisi air di Sungai Salima pada bagian tengah relatif jernih sampai sedikit mulai keruh. Vegetasi yang ada pada bahu sungai yaitu $A$. moluccana, $P$. mercusii dan berbagai tumbuhan bawah. Pada bagian tengah sungai menuju ke hilir oleh sebagian masyarakat telah membuka persawahan. Air Sungai Salima dimanfaatkan oleh masyarakat sebagai sumber air keperluan sehari-hari dan untuk mengairi lahan pertaniannya.

Bagian hilir Sungai Salima ditandai dengan adanya air yang mengalir dan juga sebagian tergenang di beberapa tempat, serta adanya bebatuan besar (Gambar 2C). Kondisi air pada bagian hilir Sungai Salima dapat dikategorikan sebagai air yang mulai terkontaminasi dengan bahanbahan organik, ditandai dengan airnya yang keruh. Vegetasi yang terdapat pada bahu sungai yaitu jenis rumput untuk pakan hewan ternak dengan jenis Pennisetum purpupoides, dan areal persawahan. Pada bagian hilir ini dimanfaatkan masyarakat sebagian untuk mengalirkan air di sistem irigasi persawahan, air untuk keperluan sehari-hari dan memandikan hewan ternak seperti sapi, kerbau dan kuda.

Tabel (Table) 1. Nilai toleransi dari famili serangga akuatik (Tolerance value of aquatic insects family) (Hilsenhoff 1988)

\begin{tabular}{|c|c|}
\hline Ordo (Order) & Familia dan nilai toleransinya (Familia and tolerance value) \\
\hline Ephemeroptera & $\begin{array}{l}\text { Baetidae 4, Baetiscidae 3, Caenidae 7, Ephemerellidae 1, Ephemeridae 4, Heptageniidae } \\
\text { 4, Leptophlebiidae 2, Metretopodidae 2, Oligoneuriidae 2, Polymitarcyidae 2, } \\
\text { Potomanthidae 4, Siphlonuridae 7, Tricorythidae } 4\end{array}$ \\
\hline Odonata & $\begin{array}{l}\text { Aeshnidae 3, Calopterygidae 5, Coenagrionidae 9, Cordulegastridae 3, Corduliidae 5, } \\
\text { Gomphidae 1, Lestidae 9, Libellulidae 9, Macromiidae } 3\end{array}$ \\
\hline Trichoptera & $\begin{array}{l}\text { Brachycentridae 1, Helicopsychidae 3, Hydropsychidae 4, Hydroptilidae 4, } \\
\text { Lepidostomatidae 1, Leptoceridae 4, Limnephilidae 4, Molannidae 6, Philopotamidae 3, } \\
\text { Phryganeidae 4, Polycentropodidae 6, Psychomyiidae 2, Sericostomatidae } 3\end{array}$ \\
\hline
\end{tabular}


Tabel (Table) 2. Kualitas air berdasarkan (Water quality based on) HFBI (Hilsenhoff 1988).

\begin{tabular}{|c|c|c|}
\hline Nilai (value) HFBI & Kualitas air (Water quality) & Tingkat pencemaran (Pollution level) \\
\hline $0,00-3,75$ & Sangat baik (very good) & $\begin{array}{l}\text { Tidak terpolusi bahan organik (not } \\
\text { polluted by organic matter) }\end{array}$ \\
\hline $3,76-4,25$ & Baik sekali (very good) & $\begin{array}{l}\text { Sedikit terpolusi bahan organik (slightly } \\
\text { polluted by organic matter) }\end{array}$ \\
\hline $4,26-5,00$ & Baik (good) & $\begin{array}{l}\text { Terpolusi beberapa bahan organik } \\
\text { (polluted by organic matter) }\end{array}$ \\
\hline $5,01-5,75$ & Cukup (moderate) & $\begin{array}{l}\text { Terpolusi agak banyak (moderately } \\
\text { polluted) }\end{array}$ \\
\hline $5,76-6,50$ & Agak buruk (slightly poor) & Terpolusi banyak (highly polluted) \\
\hline $6,51-7,25$ & Buruk (poor) & $\begin{array}{l}\text { Terpolusi sangat banyak (very highly } \\
\text { polluted) }\end{array}$ \\
\hline $7,26-10,00$ & Buruk sekali (very poor) & $\begin{array}{l}\text { Terpolusi berat bahan organik (highly } \\
\text { polluted by organic matter) }\end{array}$ \\
\hline
\end{tabular}
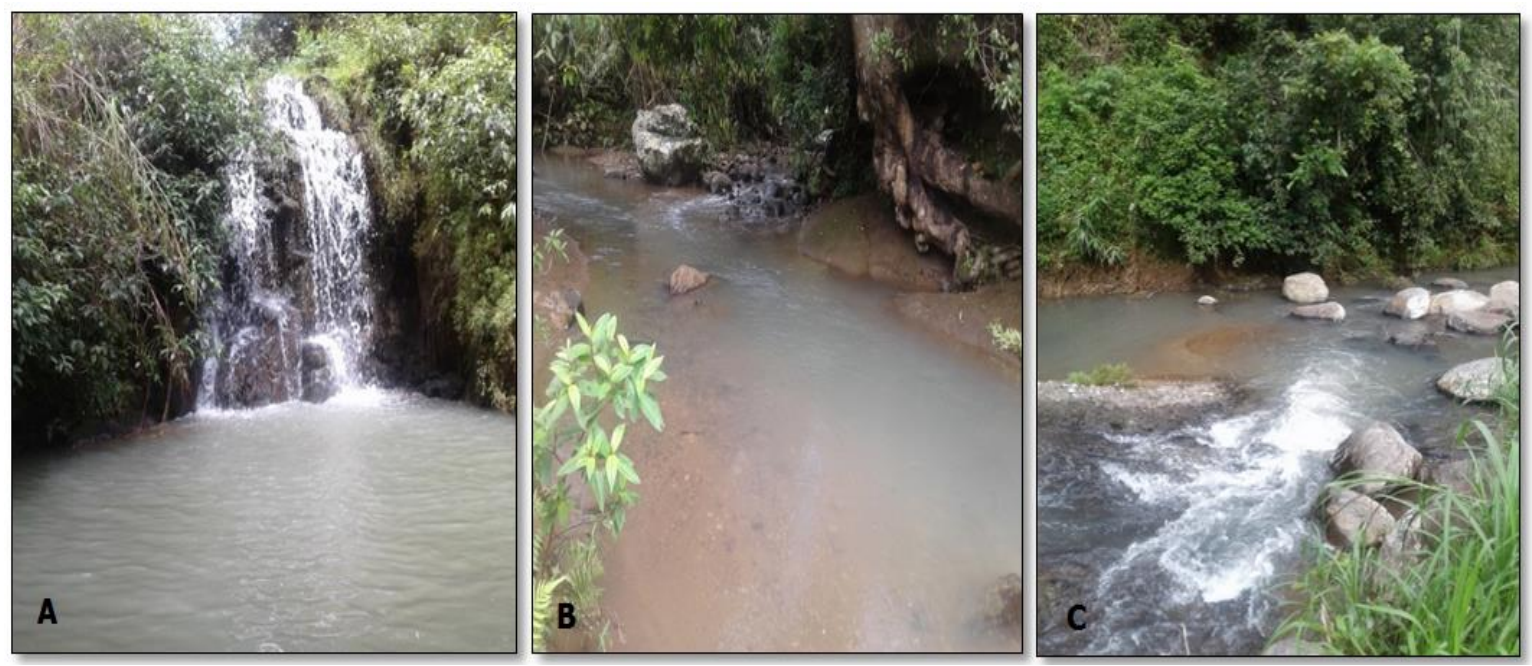

Gambar (Figure) 2. Bagian Hulu (A), Bagian Tengah (B) dan hilir (C) Sungai Salima (upstream (A), middle $(B)$ and downstream $(C)$ of the Salima River).

Sungai Salima merupakan bagian dari Daerah Aliran Sungai Bila-Walanae yang terdiri atas beberapa percabangan anak sungai yang melewati beberapa petak kerja Hutan Pendidikan Unhas. Sungai ini termasuk dalam tipe sungai periodik yaitu dipengaruhi oleh curah hujan yang dimana pada musim penghujan sungai ini akan mengalirkan air yang cukup banyak, sebaliknya apabila musim kemarau akan mengalirkan air dengan jumlah yang sedikit. Menurut Soma \& Arsyad (2014), bahwa peta penutupan vegetasi yang menyusun area di sekitar hulu Sungai Salima merupakan hutan heterogen yang ditumbuhi oleh jenis $P$. mercusii, Lento- lento (Anthropylum sp.), Sengon (Paraserianthes falcataria) dan Akasia (Acasia sp). Sedangkan bagian tengah dan hilir Sungai Salima sudah mulai terbuka tersisa $30-60 \%$ vegetasi.

\section{B. Keanekaragaman serangga di Sungai Salima}

Keanekaragaman jenis dan kelimpahan serangga akuatik berbeda pada bagian hulu, tengah dan hilir Sungai Salima. Pada setiap bagian Sungai Salima didominasi oleh Ordo Hemiptera, yaitu $54 \%$ pada bagian hulu dan $74 \%$ pada bagian tengah dan hilir sungai (Gambar 3). 


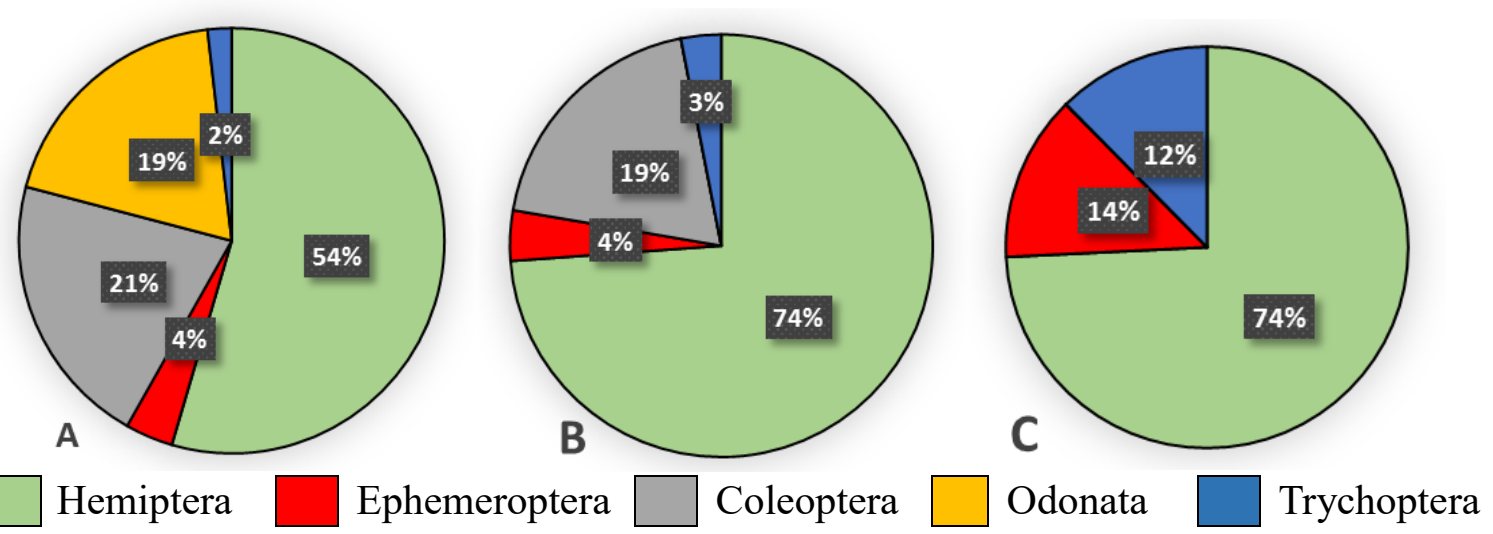

Gambar (Figure) 3. Komposisi ordo serangga akuatik yang ditemukan pada bagian hulu, tengah dan hilir Sungai Salima (The composition of the order of aquatic insects found in the upstream, middle and downstream parts of the Salima River)

Hemiptera, Trychoptera dan Ephemeroptera ditemukan di tiga bagian sungai dengan persentase yang berbedabeda. Ordo Coleoptera ditemukan di bagian hulu dan bagian tengah sungai, sedangkan Ordo Odonata hanya di bagian hulu saja dalam fase nimfa (naiads). Serangga akuatik yang umum ditemukan di perairan air tawar Indonesia adalah Ordo Odonata, Coleoptera, Trichoptera, Hemiptera, Ephemeroptera, Plecoptera dan Lepidoptera (Mahajoeno, effendi, \& Ardiansyah, 2001; Candra, Langoya, Koneria \& Singkoha, 2014).

Jumlah ordo serangga akuatik yang dapat dikoleksi hanya ada lima ordo dengan jumlah jenis yang dikumpulkan mewakili masing-masing famili. Di bagian hulu ditemukan 11 familia, 11 spesies dan 110 individu. Pada bagiam tengah terdapat tujuh familia, tujuh spesies dan 130 individu. Sedangkan bagian hilir hanya empat familia dengan 97 individu (Tabel 3).

Ephemeroptera dan Trichoptera hanya ditemukan satu spesies, Coleoptera dua spesies dari famili yang berbeda pada hulu dan satu spesies pada bagian tengah. Odonata ditemukan tiga spesies dari famili yang berbeda hanya pada bagian hulu. Hemiptera merupakan ordo yang paling banyak spesiesnya ditemukan dan hampir pada semua bagian sungai. Spesies yang paling sering ditemukan pada Sungai Salima adalah spesies Gerris remigis (Hemiptera: Gerridae) yang lebih dikenal nama lokal serangga anggang-anggang. Leba, Koneri, \& Papu (2013), melaporkan bahwa satu spesies yang mewakili Ordo Hemiptera namun jumlahnya yang paling banyak ditemukan di Sungai Pajowa Kabupaten Minahasa Suawesi Utara yaitu G. remigis.

Nilai indeks keanekaragaman serangga akuatik pada bagian hulu 2,04; tengah 1,38 dan hilir 1,11. Menurut indeks Shannon-Wiener derajat keanekaragaman serangga akuatik yang di Sungai Salima termasuk kategori sedang (H' 1-3). Nilai indeks kekayaan pada bagian hulu Sungai Salima sebesar 1,05 dan pada bagian tengah dan hilir masing-masing 0,61 dan 0,40 . Menurut indeks Shannon-Wiener derajat kekayaan jenis serangga akuatik di Sungai Salima termasuk kategori sedang (R' 1-3) pada bagian hulu sedangkan di bagian tengah dan hilir termasuk kategori rendah $\left(\mathrm{R}^{\prime}<1\right)$. Secara kuantitatif nilai indeks keanekaragaman dan nilai indeks kekayaan serangga akuatik pada bagian hulu Sungai Salima lebih tinggi dibandingkan dengan bagian tengah dan hilir. Hal ini disebabkan jumlah ordo, famili, spesies dan jumlah individu lebih banyak atau lebih beragam pada bagian hulu. Kondisi habitat bagian hulu masih 
terjaga dan keragaman jenis vegetasi masih lebih tinggi yang sangat mendukung keberagaman serangga dibandingkan bagian tengah dan hilir. Schowalter (2016), keanekaragaman tanaman atau vegetasi merupakan sumber daya penyusun struktur habitat dan menjadi inang untuk mendukung keanekaragaman serangga pada suatu habitat.

Hasil penelitian yang sama didapatkan pada beberapa sungai di Indonesia yang dilakukan dengan membagi plot atau stasiun pengamatan pada daerah bagian hulu, tengah sampai ke hilir. Hasil analisis data indeks keanekaragaman jenis pada umumnya sungai di Indonesia menunjukkan nilai indeks keanekaragaman jenis serangga air berkisar 1-3 atau kategori sedang (Maramis \& Makal, 2011; Wahizatul, Long, \& Ahmad, 2011; Marpuang, Muhammad, \& Hidayat, 2014), sementara di bagian hilir nilai indeks keanekaragaman jenisnya di bawah angka satu atau kategori rendah (Leba et al., 2013). Nilai indeks keanekaragaman serangga akuatik dengan menggunakan metode analisis yang sama di Sungai Keniam di Malaysia berkisar 1,16-2,28 (Rasdi et al., 2012) dan di Sungai Huai Kayeng dan Huai Pakkok di Thailand berkisar 2,62 - 3,2 (Maneechan \& Prommi, 2015).

Beberapa jenis serangga sangat peka terhadap tekanan lingkungan sehingga pengukuran awal dari keanekaragaman dan kekayaan jenis menjadi sangat penting. Dari data ini pula akan dapat menjadi acuan untuk pengembangan penelitian yang sama dari waktu ke waktu pada lokasi yang sama untuk menilai perubahan lingkungan Hutan Pendidikan Unhas. Potensi perubahan lingkungan tersebut sangat tinggi karena akses masyarakat ke Hutan Pendidikan Unhas sangat terbuka. Selain tujuan jangka panjang untuk kelestarian Hutan Pendidikan dan yang harus dipertahankan adalah keberadaan dan keaneragaman jenis hayati termasuk serangga-serangga akuatik. Menurut Magurran (2004), bahwa pemilihan metodologi pengukuran keanekaragaman dan kekayaan jenis harus disesuaikan dengan gagasan atau ide suatu penelitian.

Tabel (Table) 3. Kelimpahan serangga akuatik, Indeks Keanekaragaman dan Indeks Kekayaan di Sungai Salima (Abundance of aquatic insects, Diversity Index and Richness Index in the Salima River).

\begin{tabular}{|c|c|c|c|c|c|}
\hline \multirow[t]{2}{*}{ Ordo (Order) } & \multirow[t]{2}{*}{ Famili (Familia) } & \multirow[t]{2}{*}{ Spesies (Species) } & \multicolumn{3}{|c|}{$\begin{array}{l}\text { Kelimpahan spesies di bagian (The } \\
\text { abundance of species in parts) }\end{array}$} \\
\hline & & & $\mathrm{A}$ & $\mathrm{B}$ & $\mathrm{C}$ \\
\hline \multirow[t]{4}{*}{ Hemiptera } & Nepidae & Curicta volxemi & 4 & 10 & - \\
\hline & Gerridae & Gerris remigis & 30 & 70 & 58 \\
\hline & Naucoridae & Ilycoris $\mathrm{sp}$ & 6 & 2 & - \\
\hline & Notonectidae & Notonecta virescens & 20 & 14 & 14 \\
\hline Trichoptera & Hydropsychidae & $\begin{array}{l}\text { Cheumatopsyche } \\
\text { caprotina }\end{array}$ & 2 & 4 & 12 \\
\hline Ephemeroptera & Baetidae & Ecdyonurus sp. & 4 & 5 & 13 \\
\hline \multirow{3}{*}{ Odonota } & Macromiidae & Macromia sp. & 3 & - & - \\
\hline & Gomphidae & Gomphidia sp. & 3 & - & - \\
\hline & Pseudostigmatidae & Mecistogaster ornata & 15 & - & - \\
\hline \multirow[t]{2}{*}{ Coleoptera } & Gyrinidae & Dineutus sp. & 18 & 25 & - \\
\hline & Dysticidae & Cybister Fimbriolatus & 5 & - & - \\
\hline \multicolumn{3}{|c|}{ Jumlah spesies (S) } & 11 & 7 & 4 \\
\hline \multicolumn{3}{|c|}{ Jumlah individu $(\mathrm{N})$} & 110 & 130 & 97 \\
\hline \multicolumn{3}{|c|}{ Indeks Keanekaragaman (H') } & 2,04 & 1,38 & 1,11 \\
\hline \multicolumn{3}{|c|}{ Indeks Kekayaan (R) } & 1,05 & 0,61 & 0,40 \\
\hline
\end{tabular}

Keterangan (Notes): A: Hulu (upstream), B: Tengah (middlestream), C: Hilir (downstream). 


\section{Kualitas perairan Sungai Salima berbasis nilai HFBI}

Sesuai hasil perhitungan dengan menggunakan HFBI (Tabel 1) dan klasifikasi kualitas (Tabel 2), maka dapat ditentukan kualitas perairan di hulu, tengah, dan hilir Sungai Salima sebagaimana disajikan pada Tabel 4. Nilai HFBI di hulu adalah 3 yang menunjukkan kualitas perairannya sangat baik yang berarti tingkat pencemaran katagori tidak terpolusi bahan organik. Sedangkan di bagian tengah dan hilir Sungai Salima nilai HFBI 4 yang menunjukkan kualitas perairannya baik sekali dan tingkat pencemaran masuk kategori sedikit terpolusi bahan organik. Penilaian indeks biotik ini menjadi penting yang sangat membantu untuk menilai kesehatan sungai (Goncalves \& Menezes, 2011). Nilai HFBI 3 yang sama ditemukan pula pada hulu Sungai Jangkok, Lombok, Nusa Tenggara Barat dengan kondisi hetero- genitas habitat belum terganggu (Diantari, Ahyadi, Rohyani, \& Suana, 2017) dan hulu Sungai Kaliani di India (Moran, 2016).

Kondisi hutan alam heterogen yang masih terpelihara pada bagian bahu dan di sekitar hulu Sungai Salima menjadikan habitat yang sesuai untuk Famili Hydropsychidae (Trichoptera), Famili Baetidae (Ephemeroptera), Famili Macromiidae dan Famili Gomphidae (Odonata). Kelimpahan spesies dari Trichoptera dan Ephemeroptera lebih tinggi pada bagian hilir dibandingkan pada bagian hulu, akan tetapi kehadiran dua spesies dari Ordo Odonata turut mempengaruhi nilai HFBI pada bagian hulu. Menurut Bytyci et al. (2018), nilai HFBI rendah (kategori tidak terpolusi bahan organik) ditemukan pada morfologi sungai di bagian hulu yang masih alami, belum mengalami modifikasi dan dampak antropogenik masih rendah.

Tabel (Table) 4. Nilai HFBI dan penentuan kualitas perairan di bagian hulu, tengah dan hilir dari Sungai Salima. (HFBI value and determination of the quality of the water in the upstream, middle and downstream parts of the Salima River).

\begin{tabular}{|c|c|c|c|c|c|c|c|c|}
\hline \multirow[t]{2}{*}{ Ordo (Order) } & \multirow{2}{*}{$\begin{array}{l}\text { Famili } \\
\text { (Familia) }\end{array}$} & \multirow{2}{*}{$\begin{array}{l}\text { Nilai Toleransi } \\
\text { (Tolerance Value) }\end{array}$} & \multicolumn{3}{|c|}{$\begin{array}{c}\text { Jumlah Spesies } \\
\text { (Number of Species) }\end{array}$} & \multicolumn{3}{|c|}{ Nilai (Value) HFBI } \\
\hline & & & $\mathrm{A}$ & $\mathrm{B}$ & $\mathrm{C}$ & $\mathrm{A}$ & $\mathrm{B}$ & $\mathrm{C}$ \\
\hline Trichoptera & Hydropsychidae & 4 & 2 & 4 & 12 & 8 & 16 & 48 \\
\hline Ephemeroptera & Baetidae & 4 & 4 & 5 & 13 & 16 & 20 & 52 \\
\hline \multirow{2}{*}{ Odonata } & Macromiidae & 3 & 3 & 0 & 0 & 9 & 0 & 0 \\
\hline & Gomphidae & 1 & 3 & 0 & 0 & 3 & 0 & 0 \\
\hline & Total & & 12 & 9 & 25 & 36 & 36 & 100 \\
\hline \multicolumn{6}{|c|}{ Nilai HFBI } & 3 & 4 & 4 \\
\hline \multicolumn{6}{|c|}{ Evaluasi kualitas air menggunakan Family-Level Biotic Index } & $\begin{array}{c}\text { Sangat } \\
\text { baik } \\
\text { (very } \\
\text { good) }\end{array}$ & \multicolumn{2}{|c|}{$\begin{array}{l}\text { Baik sekali } \\
\text { (very good) }\end{array}$} \\
\hline \multicolumn{6}{|c|}{ Tingkat pencemaran (Pollution level) } & $\begin{array}{l}\text { Tidak } \\
\text { terpolusi } \\
\text { bahan } \\
\text { organic } \\
\text { (not } \\
\text { polluted } \\
\text { by } \\
\text { organic } \\
\text { matter) }\end{array}$ & \multicolumn{2}{|c|}{$\begin{array}{c}\text { Sedikit } \\
\text { terpolusi bahan } \\
\text { organic } \\
\text { (slightly } \\
\text { polluted by } \\
\text { organic matter) }\end{array}$} \\
\hline
\end{tabular}

Keterangan (Notes): A: Hulu (upstream), B: Tengah (middlestream), C: Hilir (downstream) 
Pada bagian tengah dan hilir Sungai Salima mulai sedikit terganggu oleh aktivitas masyarakat sekitar sehingga sudah mulai terpolusi bahan organik. Menurut Bowles \& Courtney (2018), gangguan antropogenik karena aktivitas manusia dapat mengancam keanekaragaman dan integrasi hayati terutama habitat air tawar sangat rentan terhadap tekanan lingkungan. Sungai dengan tingkat aktivitas manusia yang cukup tinggi seperti pembangunan perumahan, perkebunan dan tambang pasir mulai dari hulu sampai hilir menyebabkan tingkat pencemaran perairan sungai yang buruk sampai sangat buruk dengan nilai HFBI 6,25-7,05 (Manalu, Fajri, \& Adriama, 2014). Nilai HFBI dapat lebih tinggi bahkan mencapai angka 8 tingkat pencemaran paling parah pada sungai yang menjadi pembuangan limbah kilang minyak seperti yang terjadi di India (Moran, 2016).

Kehadiran serangga air sangat penting dalam suatu ekosistem perairan dikarenakan berbagai perannya termasuk sebagai biomonitoring dalam badan air seperti sungai. Beberapa famili dari ordoordo tertentu telah melalui penelitian panjang untuk menentukan respon toleransinya terhadap kondisi lingkungan perairan. Menurut Hilsenhoff (1988), penggunaan HFBI bermanfaat untuk mengevaluasi status umum pencemaran organik dalam aliran sungai berdasarkan nilai toleransi masing-masing famili yang telah ditentukan. Penggunaan metode HFBI telah dibandingkan dengan beberapa metode lain untuk menilai tingkat pencemaran. Penggunaan metode HFBI penilaiannya lebih peka terhadap beberapa ordo serangga dibandingkan dengan metode lain seperti EPT (persentase dari ordo Ephemeroptera, Plecoptera dan Trichoptera), BMWP (Biological Monitoring Work Party System), BMWP-ASPT (Average Score per Taxon) (Goncalves \& Menezes, 2011).

\section{KESIMPULAN DAN SARAN}

\section{A. Kesimpulan}

Jumlah keselurahan serangga yang ditemukan sebanyak 337 individu yang terdiri atas lima ordo 11 familia, dan 11 genera, ordo yang paling dominan adalah Hemiptera. Gerris remigis merupakan spesies paling banyak ditemukan di sepanjang sungai. Indeks keanekaragaman serangga aquatik Sungai Salima dari hulu sampai hilir berkisar 2,04-1,11 atau kategori sedang. Indeks kekayaan pada bagian hulu 1,05 atau kategori kekayaan sedang dan pada bagian tengah sampai hilir masing-masing 0,61 dan 0,40 atau kategori kekayaan rendah. Nilai HFBI pada bagian hulu adalah 3 yang menunjukkan bahwa kualitas perairannya sangat baik. Pada bagian tengah dan hilir, nilai HFBI sebesar 4 atau masuk kategori baik.

\section{B. Saran}

Pengukuran keanekaragaman serangga air perlu dilakukan untuk menilai kualitas perairan pada beberapa sungai di Hutan Pendidikan Unhas yang paling banyak diakses oleh masyarakat sekitar. Pengukuran ini merupakan salah satu metode yang murah dan cepat dan sekaligus menjadi sumber data awal untuk perubahan lingkungan dari waktu ke waktu (biomonitoring).

\section{UCAPAN TERIMA KASIH}

Terima kasih kepada Pengelola Hutan Pendidikan Universitas Hasanuddin yang telah menyediakan fasilitas selama penelitian.

\section{DAFTAR PUSTAKA}

Bowles, D. E., \& Courtney, G. W. (2018). Advances in aquatic insect systematics and biodiversity in the neotropics: introduction. Aquatic Insects, 39(3), 89-93. doi: 10.1080/01650424.2018.1487566. 
Bytyci, P. S., Etemi, F. N. Z., Ismaili, M. A., Shala, S. A., Serbinovski, M. S., Cadraku, H. S \& Fetoshi, O. B. (2018). Biomonitoring of water quality of River Nerodime based on physicochemical parameters and macroinvertebrates. Rasayan $J$. Chem, 11(2), 554-568. http://dx.doi.org/10.31788/RJC.2018. 1122087

Candra, Y., Langoya, M., Koneria, R. \& Singkoha, M. F. O. (2014). Kelimpahan serangga sir di Sungai Toraut Sulawesi Utara. Jurnal MIPA Unsrat Online, 3, 74-78.

Chouldhary, A. \& Ahi, J. (2015). Biodiversity of freshwater insects: a review. The International Journal of Engineering and Sciense (IJES), 4(10), 25-31.

Diantari, N. P. R., Ahyadi, H., Rohyani, I. S., \& Suana, I. W. (2017). Keanekaragaman serangga Ephemeroptera, Plecoptera, dan Trichoptera sebagai bioindikator kualitas perairan di Sungai Jangkok, Nusa Tenggara Barat. Jurnal Entomologi Indonesia, 14(3), 135142.

Easton, J. A., Huselid, L. \& Abreu, A. (2012). Invertebrate identification guide. Florida: International University Aquatic Ecology Lab. p.53.

Goncalves, F. B., \& Menezes, M .S. (2011). A comparative analysis of biotic indices that use macroinvertebrates to assess water quality in a coastal river of Paraná state, southern Brazil. Biota Neotrop, 11(4), 27-36. http://www. biotaneotropica.org.br/v11n4/en/abstr act?article+bn00411042011.

Gullan, P. J. \& Cranston, P. S. (2014). The insects: an outline of entomology. Fifth Edition. West Sussex: John Wiley \& Sons, Ltd. p. 632.

Hilsenhoff, W. L. (1988). Rapid field asessment of organic pollution with a family-level biotic index. Journal of the North American Benthological Society 7, 65-68. doi: https://doi. org/10.2307/1467832.

Leba, G. V., Koneri, R., \& Papu, A. (2013). Keanekaragaman serangga air di Sungai Pajowa Kabupaten Minahasa, Sulawesi Utara. Jurnal MIPA Unsrat Online, 2(2), 73-78.

Magurran, A. E. (2004). Measuring biological diversity and its measurement. Oxford: Blackwell Publishing. p. 256

Mahajoeno, E., Efendi, M., \& Ardiansyah. (2001). Keanekaragaman larva insekta pada sungai-sungai kecil di hutan Jobolarangan. Biodiversitas, 2, 133-139. doi: 10.13057/biodiv/ d020202.

Manalu, I., Fajri, N. E., \& Adriama. (2014). Determination of water pollution levels Sibam River Pekanbaru based biotic index macrozoobenthos. JOM, 1-9. https://media.neliti.com/media/public ations/199086-none.pdf

Maneechan, W., \& Prommi, T. O. 2015. Diversity and distribution of aquatic insects in streams of the Mae Klong Watershed, western Thailand. Psyche, 1-7.

http://dx.doi.org/10.1155/2015/91245 1

Maramis, R. T. D., \& Makal, H. V. G. (2011). Keanekaragaman jenis dan kelimpahan populasi serangga air sebagai indikator biologis cemaran air pada DAS di Langowan. Eugenia, 17(2), 95-101.

Marpuang, S. M., Muhammad, F., \& Hidayat, J. W. (2014). Keanekaragaman dan kemelimpahan larva insekta akuatik sebagai bioindikator kualitas air di Sungai Garang, Semarang. Jurnal Biologi, $3(4), 1-8$.

Moran, J. (2016). Application of family biotic index in assessment of two 
rivers affected by oil pollution in Assam, India. International Research Journal of Environment Sciences, $5(11), 35-40$.

Morse, J. C. (2009). Biodiversity of aquatic insects. In: Foottit, R.G., \& Adler, P.H., (eds.). Insect Biodiversity: Science and Society. Oxford: Blackwell Publishing Ltd. Pp. 165-263.

Nair, G. A., Morse, J. C., \& Marshall, S. A. (2015). Aquatic insects and their societal benefits and risks. Journal of Entomology and Zoology Studies 3(3), 171-177.

Prommi, T. \& Payakka, A. (2015). Aquatic insect biodiversity and water quality parameters of streams in Northern Thailand. Sains Malaysiana, 44, 707-717. doi: 10.17576/jsm-2015-4405-10.

Rasdi M. Z., Fauziah, I., Ismail, R., Mohd, Hafezan, S., Fairuz K., Hazmi, A. D., \& Che Salmah. M. R. (2012). Diversity of aquatic insects in Keniam River, National Park, Pahang, Malaysia. Asian Journal of Agriculture and Rural Development, 2(3), 312-32.
Samways, M. J. (2018). Insect conservation for the twenty-first century. In: Shah, M.M. \& Syarif, U. (eds.). Insect Science-Diversity, Conservation and Nutrition. London: IntechOpen. Pp. 19-40. doi: http://dx.doi.org/10.5772/intechopen. 71639.

Schowalter, T.D. (2016). Insect ecology: An ecosystem approach. Fourth edition. London: Academic Press. P. 753.

Soma, A.S., \& Arsyad, U. (2014). Pemetaan faktor penutupan vegetasi pada hutan homogen dan heterogen Hutan Penidikan Universitas Hasanuddin, hulu Daerah Aliran Sungai Bila-Walanae. Jurnal Satria Seri Ilmu Pengetahuan Alam. 20, 20 37.

Wahizatul, A. A., Long, S. H., \& Ahmad, A. (2011). Composition and distribution of aquatic insects communities in relation to water quality in two freshwater streams of hulu Terengganu, Terengganu. Journal of Sustainability Science and Management, 6(1), 148-155. 